\title{
野菜類を加害するコナダ二類に関する研究
}

\section{II. 野菜類の育苗期におけるコナダニ類の加害}

\author{
中尾弘 志 ${ }^{11}$ \\ 北海道立中央農業試験場
}

Studies on Acarid Mites (Acari: Astigmata) Damaging Vegetable Plants. II. Damage to Vegetable Seedlings. Hiroshi NAkao ${ }^{2)}$ (Hokkaido Central Agricultural Experiment Station, Naganuma, Hokkaido 069-13, Japan). Jpn. J. Appl. Ent. Zool. 35: 303-309 (1991)

Plant-pest surveys on acarid mites damaging vegetable seedlings were conducted in 63 districts of Hokkaido for 10 years from 1981 to 1990 . In 39 districts, at least one of five species of the acarid mites, Tyrophagus putrescentiae (Schrank), T. similis Volgin, T. perniciosus Zachvatkin, Acarus immobilis GRIFFITHS and Rhizoglyphus robini Claparède, was collected from seedlings, soil, rice chaff and/or rice straw. Three species of the genus Tyrophagus were damaging to vegetable seedlings: T. putrescentiae; melon, watermelon cucumber and pumpkin, $T$. similis; melon, watermelon, cucumber, pumpkin, tomato, sweet pepper and welsh onion, $T$. perniciosus; melon, cucumber and pumpkin. The symptoms of damage by acarid mites are summarized as follows: (a) melon, cucumber, pumpkin; numerous small holes and yellowish spots on young leaves which later become deformed, (b) watermelon, tomato, sweet pepper; leaves become lustrous, discolored and deformed, (c) tomato, welsh onion; seedlings become dwarfed and stunted. A survey on the source of acarid mites in greenhouses showed that the mites originate from rice chaff and/or rice straw used for lagging so these mites are introduced into the greenhouse. A tarsonemid mite, Tarsonemus bilobatus Susuki, which may be harmful to vegetables, was also collected from melon, watermelon, cucumber and Chinese cabbage. The symptom of damage is lustrous, discolored and deformed leaves with irregular folding of the upper surface.

Key words: vegetable seedlings, acarid mites, Tyrophagus, rice chaff, rice straw

緒言

コナダニ類はこれまで貯穀, 食品, 衛生害虫として 問題となることが多く，わが国でもこれらの研究が古く から行われてきた(大島，1977；佐々，1970)。また，農 作物への被害も知られており, Tyrophagus 属のコナダ ニであるホウレンソウケナガコナダニ Tyrophagus similis VOLGIN によるベルギーの温室ホウレンソウ (BRUEL, 1940), イタリアのメロン (LAFFI, 1980), オンシッケナ ガコナダニ T. neiswanderi JoHnston et BRUCE によるオ ハイオ州の温室キュウリ (JoHNSTON and BRUCE, 1965) などの被害例がある。わが国でも，ケナガコナダニ $T$. putrescentiae (SCHRANK) が温室・八ウス栽培のキュウリ (江原・真梶, 1975; 小林・深沢, 1983), ナス, 八クサ
イ，トマトの育苗床 (藤本・足立，1977）などで大きな 被害を与えていることが報告されている。

北海道では, 1975 年に音更町のハウス栽培ホウレン ソウでュナダニ類による被害が，さらに1980年には共 和町の育苗中のメロン，スイカでコナダニ類やホコリダ 二類による被害が確認された(中尾, 1988)。コナダニ 類は雌成虫でも胴長約 $500 \mu \mathrm{m}$ 内外と小さく，被害植物 が乾燥するとすぐに移動したり死亡しやすいために発見 が難しく，原因不明の生理障害あるいは生育異常として 見過ごされてきた可能性が高い。このため，加害種やそ の生態, 被害状況などは注とんど不明であった。農作物 を加害するコナダ二類のらち，4 種の形態と分布, なら びにそれらによる被害については中尾・黒佐 (1988) が, また，ホウレンソウに拈けるコナダニ類の加害実態につ

1) 現在 北海道立上川農業試験場

2) Present address: Hokkaido Prefectural Kamikawa Agricultural Experiment Station, Nagayama, Asahikawa 079, Japan.

1991 年 5 月 21 日受領 (Received May 21, 1991)

1991 年 7 月 18 日登載決定 (Accepted July 18, 1991) 
いては，前報で報告した（中尾，1989）。今回は，野菜 類の育苗期に発生し加害するコナダ二類の加害実態につ いて調査をおこなったので報告する。

本文に入るに先立ち，北海道立中央農業試験場専技 室, 全道各地の農業改良普及所の各位に多大な協力をい ただいたことに御礼申し上げる。研究の当初より多くの 援助と助言をいただいた，元北海道立中央農業試験場病 虫部長故富岡暢氏に深く感謝する。また，本稿の校閲お よび多くの助言をいただいた北海道大学農学部斎藤裕博 土ならびに北海道立中央農業試験場害虫科長梶野洋一博 士に感謝の意を表する。

\section{調 査 方 法}

\section{1. コナダニ類の分離方法と同定}

土䫓, モミガラ, 稻わらからのコナダ二類の分離はツ ルグレン法に準じた装置を用い, 試料を $40 \mathrm{~W}$ 電球で (土壌表面から約 $8 \mathrm{~cm}$ ) 48 時間乾燥させて, $70 \%$ エタ ノール入りの管瓶に落下したダニを集め分離した。植物 体付着ダニは被害状況を調查したのち，70\%エタノー ル中でサンプルを十分に振って分離した。

種の同定は, コナダニ類をプレパラート標本にし，光 学顕微鏡によって打こなった。

\section{2. 被害実態調査}

北海道に打けるコナダニ類の被害実態を明らかにする ため, 1981〜1990 年に道内 17 市町村に打いて, 育苗中 のメロン, スイカ, キュウリ, カボチャ, 長ネギ, トマ トおよびピーマンの被害状況を調查した。同時に土埣, モミガラ, 稲わら, 植物体を採集し, コナダニ類の種類 および密度を調査した。

\section{3. 被害発生地での発生密度調查}

コナダニ類の発生量と被害との相関関係を明らかにす るため, 被害が発生した現地ハウス、に打いて 1983〜1990 年に発生密度を調査した。メロソは 3 か年 3 地点, キュ ウリは 2 か年 3 地点, カボチャ颃よび長ネギは 2 か年 2

Table 1. Temperatures recommended for growing various vegetable plants

\begin{tabular}{lcr}
$\begin{array}{c}\text { Cultivated } \\
\text { plant }\end{array}$ & Seeding stage & Seedling stage \\
\hline Sweet pepper & $30-35^{\circ} \mathrm{C}$ & $25-30^{\circ} \mathrm{C}$ \\
Melon & $28-30^{\circ} \mathrm{C}$ & $25-28^{\circ} \mathrm{C}$ \\
Cucumber & $25-30^{\circ} \mathrm{C}$ & $25^{\circ} \mathrm{C}$ \\
Pumpkin & $25-30^{\circ} \mathrm{C}$ & $18-20^{\circ} \mathrm{C}$ \\
Tomato & $20-28^{\circ} \mathrm{C}$ & $18-25^{\circ} \mathrm{C}$ \\
Welsh onion & $15-20^{\circ} \mathrm{C}$ & $15-20^{\circ} \mathrm{C}$ \\
\hline
\end{tabular}

地点, トマト拉よびピーマンは 1 地点を前述と同様の方 法で扰こなった。これらの作物の育苗適温はTable 1 の よらにまとめられ，一般に現地のハウスではこれに準じ て育苗管理を実施している。

\section{4. 現地における発生源調査と载培概要}

コナダニ類の発生源を明らかにするため，栗沢町の現 地農家ハウスで 1983〜1986 年までキュウリの播種床お よび移植ポット用の土壤と保温資材として使用するモミ ガラに打けるコナダ二類の生息状況を調查した。

育苗方法は農家慣行法に準じた。育苗および移植ポッ ト用の土壤を前年の秋にモミガラ, くん炭, ピートモス を土に混ぜて準備し，ビニールで被覆して臭化メチルく ん蒸剤処理を括こなった。モミガラは前年秋の水稲収穫 後に野づにしたものを使用した。また，播種床，育苗 床とも保温資材としてモミガラ (深さ $10 \sim 15 \mathrm{~cm}$ ) を用 い，播種床はモミガラの上にあらかじめ準備した土壌を 入れ (深さ $15 \mathrm{~cm}$ ) 播種した。育苗床はモミガラの上に ビニールシートを敷き，その上に苗を移植した育苗用ポ ットを並べて栽培した。な牧, 熱線を入れて土壤温度が $28^{\circ} \mathrm{C}$ 前後になるように設定した (Fig. 1)。

\section{結果}

\section{1. コナダニ類の同定および作物の被害症状}

コナダニ類の寄生作物とその被害症状を Table 2 に示 した。ホウレンソウケナガコナダニ Tyrophagus similis Volgin, オオケナガコナダ $=T$. perniciosus ZachVATKIN, ケナガコナダニ $T$. putrescentiae (SchraNK), ロビンネダ = Rhizoglyphus robini ClAPARÈDE 拉よびスジブトホコリ ダニ Tarsonemus bilobatus SUSUKI による加害が認められ た。寄生作物への被害は認められなかったが, ゴミコ ダニの 1 種 Caloglyphus sp. がメロンから，オソアシブト コナダニAcarus immobilis GRIFFITHS がキュウリから採集 された。

各作物のコナダニ類による被害症状は以下のようにま とめられる。

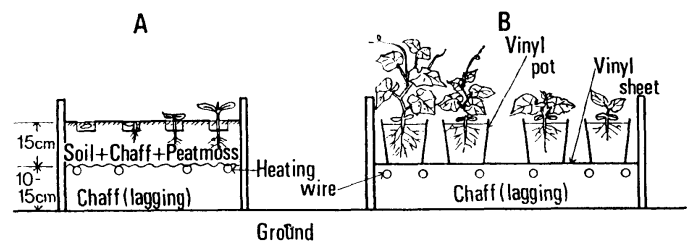

Fig. 1. Structure of cucumber seeding and seedling beds at Kurisawa. A: seeding bed, B: seedling bed. 
Table 2. Host plants and symptom of damage by acarid mites (including tarsonemid mites)

\begin{tabular}{|c|c|c|}
\hline Mite species & Host plant & $\begin{array}{c}\text { Symptom of } \\
\text { damage }\end{array}$ \\
\hline \multirow[t]{7}{*}{ Tyrophagus similis } & Melon & A \\
\hline & Watermelon & B \\
\hline & Cucumber & A \\
\hline & Pumpkin & A \\
\hline & Tomato & $\mathrm{B}, \mathrm{C}$ \\
\hline & Sweet pepper & $\mathrm{B}$ \\
\hline & Welsh onion & $\mathrm{C}$ \\
\hline \multirow{3}{*}{ Tyrophagus perniciosus } & Melon & A \\
\hline & Cucumber & A \\
\hline & Pumpkin & $\mathrm{A}$ \\
\hline \multirow[t]{5}{*}{ Tyrophagus putrescentiae } & Melon & A \\
\hline & Watermelon & $\mathrm{B}$ \\
\hline & Cucumber & A \\
\hline & Pumpkin & A \\
\hline & Sweet pepper & B \\
\hline Rhizoglyphus robini & Welsh onion & $\mathrm{C}$ \\
\hline Caloglyphus sp. & Melon & - \\
\hline Acarus immobilis & Cucumber & - \\
\hline \multirow[t]{4}{*}{ Tarsonemus bilobatus } & Melon & $\mathrm{D}$ \\
\hline & Watermelon & $\mathrm{D}$ \\
\hline & Cucumber & $\mathrm{D}$ \\
\hline & Chinese cabbage & $\mathrm{D}$ \\
\hline
\end{tabular}

A: numerous small holes and yellowish spots on young leaves which later become deformed.

B: leaves become lustrous, discolored and deformed.

C: seedlings become dwarfed and stunted.

D: leaves become lustrous, discolored and deformed with irregular folding of upper surface.

-: no damage or light damage.

a) メロンキュウリ，カボチャ：新葉に小孔，小斑 点ができ，その後，生育すると奇形になる。

b) スイカ, トマト, ピーマン：葉は光沢を帯び, 裉 色し奇形となる。

c) トマト，長ネギ：苗は萎縮し生育が止まる。

またスジブトホコリダニによる被害症状は以下のよ らであった。

d) メロン，スイカ，キュウリ，ハクサイ：葉は光沢 を帯び, 褪色し内側に巻きこみ奇形となる。

\section{2. コナダニ類採集結果}

1981〜1990 年の調査結果を市町村別に示したのが Fig. 2 である。コナダ二類は北海道内 17 市町村中, 15 市町村で採集された。ホウレンソウケナガコナダニは 9 市町村, ケナガコナダニは 7 市町村, オオケナガコナダ 二は4 市町村の植物体, 土壤, モミガラおよび稲わらか ら採集された。

Table 3 に各作物ごとの調査結果を示した。全調査点 数 63 点に対し, コナダ二類は 39 点 $(61.9 \%)$, ホウレン

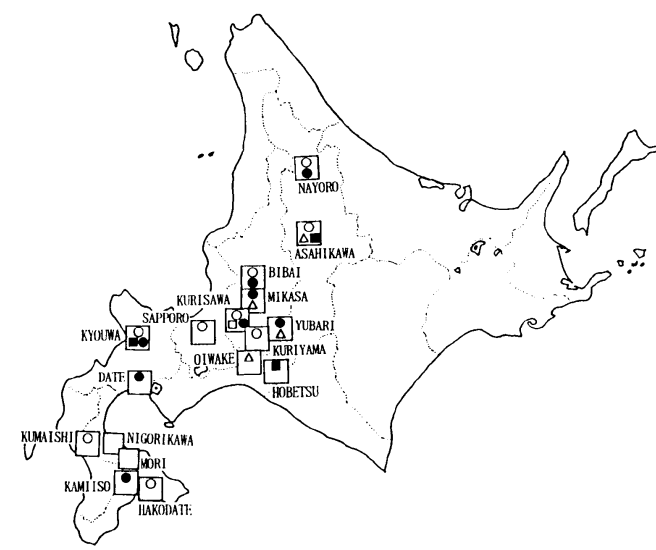

Fig. 2. Distribution of Tyrophagus similis (O), T. putrescentiae $(\bullet), T$. perniciosus $(\triangle)$, Acarus immobilis $(\square)$ and Tarsonemus bilobatus ( $\boldsymbol{\square})$ as pests of vegetable seedlings in Hokkaido.

ソウケナガコナダニは 23 点 $(37.1 \%)$ ，ケナガコナダニ は 10 点 $(16.1 \%)$ ，オオケナガュナダニは 4 点 $(6.5 \%)$ の植物体および土壤等から採集された。

これらのコナダニ類は新芽, 新葉部に集中して寄生し 加害するため, その後の生育とともに外側の展開葉は縮 葉し奇形となり，被害株は生育がかなり悪くなる。さら に被害の激しい株は生育が止まるか枯死する。発芽時に 加害されたトマトと長ネギの被害は激しく, 奇形の程度 が著しいため生育が止まり，被害株は苗として使用でき なかった。なお，スジブトホコリダニが 7 点 $(11.1 \%)$ から採集された。被害作物はメロン，スイカ，キュウリ 特よび八クサイで，その被害症状は上記のコナダニ類よ り激しく、キュウリ，ハクサイは苗として使用できなか った。

\section{3. 被害発生ほ場の生息密度調査}

1983〜1990 年の調査結果を Table 4 に示した。メ口 ソの加害の主要種はホウレンソウケナガコナダニ，オオ ケナガコナダニであった。被害は比較的軽く, 植物体,

育苗土, モミガラ, 稲わらとも密度は低かった。キュウ リの加害種はケナガコナダニ, ホウレンソウケナガコナ ダニ, オオケナガコナダニ，スジブトホコリダニで，植 物体, 育苗土, モミガラ, 稲わらとも密度は高く, 被害 株率は 30〜 100\% であった。な敃，1983 年の栗沢町に 拈けるケナガュナダニの寄生量はこれまでの調査中で最 も高く、被害株率は $100 \%$ に達し被害程度も激しかった ため，苗としてまったく使用できなかった。また，1986 年の旭川市に拉ける被害は播種床でスジブトホコリダニ 
Table 3. Occurrence of damage to vegetable plants caused by acarid mites (1981-1990; including tarsonemid mites)

\begin{tabular}{|c|c|c|c|c|c|c|}
\hline Cultivated plants & Locality & $\begin{array}{c}\text { No. } \\
\text { samples } \\
\text { examined }\end{array}$ & $\begin{array}{l}\text { Date of } \\
\text { collection }\end{array}$ & $\begin{array}{l}\text { No. samples } \\
\text { acarid mites } \\
\text { extracted }\end{array}$ & Mite species & $\begin{array}{c}\text { Degree of } \\
\text { damage }\end{array}$ \\
\hline \multirow[t]{9}{*}{ Melon } & Kyowá & 2 & April 1981 & 2 & Tarsonemus bilobatus & Medium \\
\hline & & & & & Tyrophagus similis & \\
\hline & Kyowá & 1 & May 1983 & 1 & T. similis & Light \\
\hline & Asahikawa & 2 & April 1985 & 2 & T. similis, Caloglyphus sp. & Medium \\
\hline & Hobetsu & 1 & May 1985 & 0 & Ta. bilobatus & Light \\
\hline & Yubari & 1 & May 1986 & 1 & T. perniciosus & Medium \\
\hline & Yubari & 1 & April 1987 & 1 & T. similis, Ta. bilobatus & Light \\
\hline & Yubar: & 1 & May 1989 & 1 & $T$. putrescentiae & Light \\
\hline & Oiwake & 1 & April 1986 & 1 & $T$. perniciosus & Light \\
\hline (Melon) & Date & 2 & March 1984 & 1 & T. putrescentiae & (Soil, chaff)* \\
\hline \multirow[t]{2}{*}{ Watermelon } & Kyowa & 2 & April 1981 & 2 & T. similis, Ta. bilobatus & Medium \\
\hline & Kyowa & 3 & March 1983 & 1 & T. similis, $T$. putrescentiae & Light \\
\hline \multirow[t]{6}{*}{ Cucumber } & Kurisawa & 1 & May 1983 & 1 & $T$. putrescentiaes & Severe \\
\hline & Kurisawa & 1 & May 1984 & 1 & Acarus immobilis & Null-Light \\
\hline & Kurisawa & 1 & May 1985 & 1 & Acarus immobilis, $T$. putrescentiae & $e$ Null-Light \\
\hline & Asahikawa & 1 & April 1986 & 1 & Ta. bilobatus, T. similis & Severe \\
\hline & Asahikawa & 1 & April 1986 & 1 & $T$. similis & Severe \\
\hline & Asahikawa & 1 & April 1986 & 1 & T. similis, T. perniciosus & Severe \\
\hline (Cucumber $・$ Tomato) & Kumaishi & 10 & March 1984 & 5 & $T$. similis & (Soil, chaff)* \\
\hline (Cucumber • Tomato) & Nigorikawa & 2 & March 1984 & 0 & 一 & (Soil, chaff)* \\
\hline (Cucumber $・$ Tomato) & Nayoro & 5 & April 1984 & 4 & $T$. putrescentiae, $T$. similis & (Soil, chaff)* \\
\hline (Cucumber $・$ Melon) & Hakodate & 6 & March 1984 & 2 & T. similis, Caloglyphus sp. & (Soil, chaff)* \\
\hline (Cucumber) & Mori & 3 & March 1984 & 0 & - & (Soil, chaff)* \\
\hline (Cucumber) & Kamiiso & 7 & March 1984 & 3 & T. putrescentiae, Caloglyphus sp. & (Soil, chaff)* \\
\hline \multirow[t]{2}{*}{ Pumpkin } & Sapporo & 1 & May 1984 & 1 & T. similis & Medium \\
\hline & Mikasa & 1 & June 1986 & 1 & $T$. putrescentiae, $T$. perniciosus & Light \\
\hline Tomato & Kuriy:ama & 1 & March 1989 & 1 & $T$. similis & Medium \\
\hline Sweet pepper & Bibai & 1 & March 1990 & 1 & T. similis, T. putrescentiae & Medium \\
\hline \multirow[t]{2}{*}{ Welsh onion } & Kuriy:ama & 1 & June 1988 & 1 & T. similis & Severe \\
\hline & Kuriyama & 1 & April 1990 & 1 & T. similis, Rhizoglyphus robini & Medium \\
\hline Chinese cabbage & Asahikawa & 1 & March 1984 & 0 & Ta. bilobatus & Severe \\
\hline Total & & 63 & & $39(6$ & & \\
\hline
\end{tabular}

* before sowing.

とホウレンソウケナガコナダニが混発した事例で, この ために被害株率は100\%となった。カボチャの加害の主 要種はホウレンソウケナガコナダニ, オオケナガコナダ 二で, 他の作物と比較して寄生密度が低くても奇形株に なりやすい傾向がみられた。トマトの加害種はホウレン ソウケナガコナダニで, 播種床で発生したために $80 \%$ が苗として使用できなかった。土壌 $100 \mathrm{~g}$ 当り 72 匹が 検出され，これまでの調査中で最も高かった。ピーマン の加害の主要種はホウレンソウケナガコナダニで, 寄生 密度は比較的高かったにもかかわらず被害は軽かった。 長ネギの加害種はホウレンソウケナガコナダニとロビン ネダニであった。2 か年とも $30 \%$ の被害率で, 1988 年 は播種床で発生したため被害株は完全に枯死した。調査 したハウスでは保温資材としてモミガラか稲わらを使用
しているか，使用していない場合でも育苗土にモミガラ を混ぜていた。

\section{4. 発生源調査}

ケナガコナダニが多発した栗沢町現地農家での調査結 果を Table 5 に示した。1983 年の育苗期にはケナガコ ナダニが激発し，ケナガコナダニは前年産のモミガラか ら 1983 年 10 月まで検出された。1984年のオソアシブト コナダニの発生状況を Fig. 3 に示した。前年 12 月まで 育苗土とモミガラからケナガコナダニとホウレンソウケ ナガコナダニが検出されていたが，育苗初期にはほとん ど検出されなかった。しかし，5月７日にモミガラから オソアシブトコナダニが初めて検出され，5月下旬から 6 月上旬にピークとなり播種床の表面をはいまわるほど の発生となった。モミガラに拈㤝有ステージ別の構 
Table 4. Occurrence of acarid mites at seedling stage of vegetable plants in greenhouse

\begin{tabular}{|c|c|c|c|c|c|c|c|}
\hline \multirow[b]{2}{*}{$\begin{array}{l}\text { Cultivated } \\
\text { plants }\end{array}$} & \multirow[b]{2}{*}{$\begin{array}{l}\text { Locality } \\
\text { and date }\end{array}$} & \multicolumn{4}{|c|}{ Number of mites (per or in) } & \multirow[b]{2}{*}{$\begin{array}{c}\% \text { of plant } \\
\text { injured }\end{array}$} & \multirow[b]{2}{*}{$\begin{array}{l}\text { Dominant } \\
\text { specie }\end{array}$} \\
\hline & & plant & $\begin{array}{l}\text { bed soil } \\
(100 \mathrm{~g})^{*}\end{array}$ & $\begin{array}{l}\text { rice straw } \\
(20 \mathrm{~g}) * *\end{array}$ & $\begin{array}{l}\text { rice chaff } \\
(20 \mathrm{~g})^{* *}\end{array}$ & & \\
\hline Melon & Kyowa '83 & 0 & 5.0 & - & - & $10^{2)}$ & T. similis \\
\hline Melon & Yubari '86 & 1.0 & 0 & - & 6.8 & $10^{2)}$ & T. perniciosus \\
\hline Melon & Oiwake '86 & 0 & 0 & 1.0 & - & $10^{2)}$ & T. perniciosus \\
\hline Cucumber & Kurisawa '83 & 110.4 & 554.0 & - & - & $100^{1)}$ & $T$. putrescentiae \\
\hline Cucumber & Asahikawa '86 & 30.0 & - & 25.0 & - & $100^{1)}$ & Ta. bilobatus, T. similis \\
\hline Cucumber & Asahikawa '86 & 5.2 & - & - & - & $30^{2)}$ & $T$. perniciosus \\
\hline Pumpkin & Sapporo '84 & 0.3 & 8.0 & - & - & $100^{1)}$ & $T$. similis \\
\hline Pumpkin & Mikasa '86 & 1.0 & 0.3 & - & - & $10^{1)}$ & T. perniciosus \\
\hline Tomato & Kuriyama '89 & - & 72.0 & - & - & $80^{1)}$ & $T$. similis \\
\hline Sweet pepper & Bibai '90 & 5.0 & 1.0 & - & 20.0 & $10^{1)}$ & $T$. similis \\
\hline \multirow[t]{2}{*}{ Welsh onion } & Kuriyama '88 & - & 9.0 & - & - & $30^{1)}$ & $T$. similis \\
\hline & Kuriyama '90 & 13.0 & 10.0 & - & - & $30^{3)}$ & R. robini \\
\hline
\end{tabular}

* Soil mixed with rice chaff.

** Rice straw and chaff spread for lagging under soil bed in greenhouse.

1) Acarid mites occurred in seeding bed.

2) Acarid mites occurred in seedling bed.

3) Acarid mites occurred at growing stage.

Table 5. Survey of sources of acarid mites in cucumber greenhouse at Kurisawa

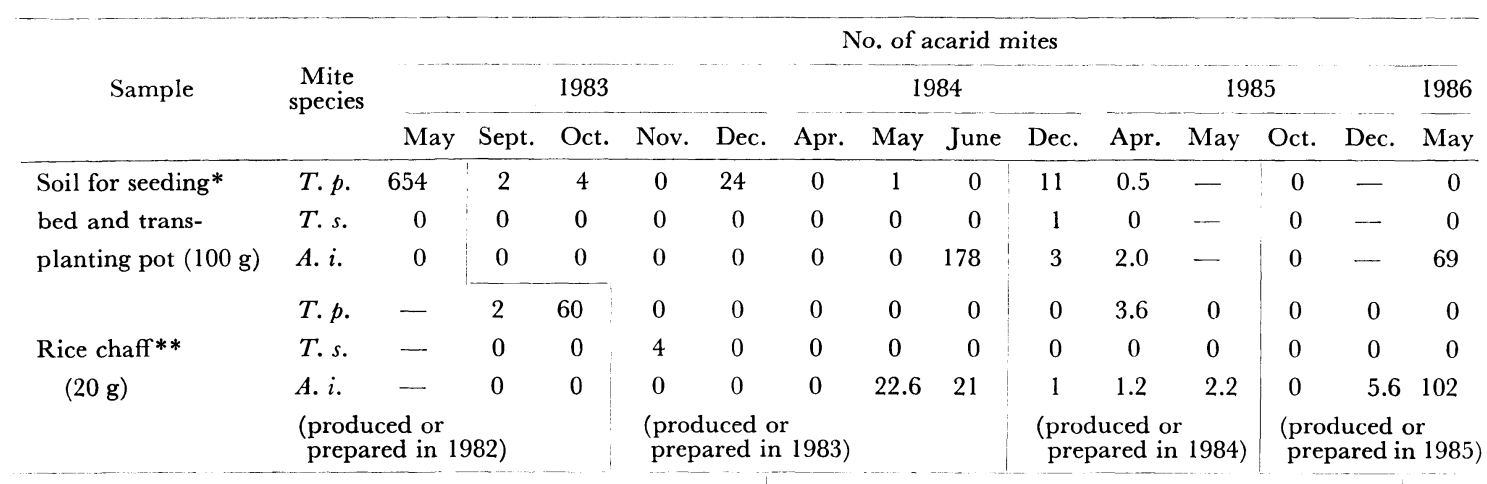

Degree

Severe

Light

Light

Light

T. p., Tyrophagus putrescentiae; T. s., Tyrophagus similis; A. i., Acarus immobilis.

* These consisted of soil, chaff and peat moss sterilized by methylbromide in the previous year.

** Chaff was produced in the previous year and spread for lagging under the soil bed in the greenhouse.

成は成虫, 幼若虫のみであった。育苗土では 5 月中旬ま で個体数は少なく，ヒポプスの割合が高く，5月下旬か ら 6 月上旬にかけて成虫が急増した。その後個体数は減 少し, 再びヒポプスの割合が増加し 6 月下旬にはヒポプ スだけになった。一方，6月下旬のモミガラからは成 虫, 幼若虫の及が検出された。1985 年はケナガコナダ ことオソアシブトコナダニが少発した。前年秋にコナダ 二類 3 種が育苗土とモミガラから検出され, 育苗期にも ケナガコナダニとオソアシブトコナダニが検出された。
1986 年はオソアシブトコナダニが激発した。前年秋の 育苗土からはまったく検出されなかったが，モミガラで は前年秋から検出され育苗期の密度も高かった。ケナガ コナダニが多発した1983 年のキュウリ被害は全株にお よんだが, 1984 年からの 3 か年の被害は非常に軽微で あった。

$$
\text { 考察 }
$$

調査した 17 市町村 63 地点中 39 地点 $(61.9 \%)$ からコ 


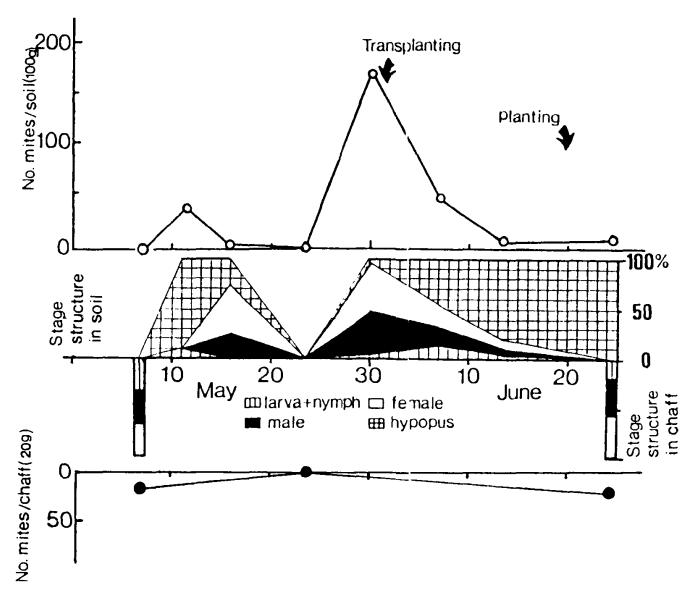

Fig. 3. Seasonal occurrence and stage structure of Acarus immobilis in cucumber greenhouse (KurIsawa, 1984).

ナダニ類が採集された。これまで本州ではコナダニ類に よる野菜の被害はキュウリ，メ政，スイカ(江原・真 梶, 1975; 小林・深沢, 1983), ナ゙ス, 八クサイ, トマト (藤本・足立, 1977) の育苗床で発生し，いずれもケナ ガコナダニが加害種として報告されている。本調査では ケナガュナダニはメロン，スイカ，キュウリ，カボチ ヤ, ピーマンから検出されたが, 主要な加害種と判断さ れた事例は激発したキュウリの1例のみであった。ホウ レンソウケナガコナダニによるトマト，ピーマンおよび 長ネギ，オオケナガコナダニによるキュウリの被害が新 たに確認された。な抏，この 2 種は全道のホウレンソウ でも被害が認められている。このらちオオケナガコナダ ニはホウソンレウで 2 地点から確認されていたが (中 尾, 1989), 新たに 4 地点で発生が認められた。

栗沢町のキュウリ栽培ハウスでオソアシブトコナダニ が多発生した。GRIFFITHS (1964)によると本種はダリア とヒヤシンスの球根, 小麦, チーズ, スズメの巣, 乾燥 小屋, 各種植物の根等から採集されている。今回の調査 では発生量が多かったにもかかわらず被害がほとんど認 められなかったことから、キュウリを加害していないと 考えられた。

コナダ二類の発生量と被害の関係は調査数が少なく， 作物によって発生量と被害の程度が異なることなどから 明確にできなかった。しかし当然のことであるが各作物 とも幼苗期に加害されると被害は大きく，播種してその まま有苗されるカボチャ, トマト，長ネギで被害が高か った。キュウリやメロンは接ぎ木栽培が普通に抏こなわ
れ，播種床でコナダ二類が発生して加害を受けた場合の 被害は大きく，接ぎ木苗としてまったく使用できなかっ た。しかし，メロンの被害例のように，接ぎ木後の育苗 休における被害は比較的軽微であり，育苗期間中のどの 時期に加害を受けるかによって，被害程度は異なると考 えられる。

育苗温度はTable 1 に示したようにピーマンで最も高 く，長ネギが最も低い。飯室 (1956)によればケナガコ ナダ二は高温・高湿を好み，繁殖最適条件は $25^{\circ} \mathrm{C}, 75 \%$ R. H. とされている。栗沢町のケナガコナダニによる被 害例は, 熱線で土壌温度を $28^{\circ} \mathrm{C}$ 前後に管理したため好 適条件になった結果であろう。ホウレンソウケナガコナ ダニはホウレンソウの調查からケナガュナダニと比較す るとやや低い温度と高湿を好むダニと考えられ（中尾， 1989), 飼育試験の結果では $25^{\circ} \mathrm{C}$ 恒温条件下で生育で きなかった (中尾，未発表)。本種はカボチャ，トマト， 長ネギの主要な加害種であるが，これらの作物では育苗 温度が比較的低いため発生に好適であると考兄られる。 一方, ピーマンに特いても本種は比較的高密度で検出さ れているが，育苗初期はむしろ高温に保たれるため発生 は抑制され，育苗中期から後期にかけての育苗温度の低 下 (熱線で土壤温度を $18^{\circ} \mathrm{C}$ に設定)にともない発生量 が増大したと考学られる。このために被害程度が低かっ たものと推定される。

土壤中のダニはツルグレン装置で分離しているため, 活動期の個体しか抽出されず，成虫に比べ幼虫，若虫の 抽出数は少ない傾向があり，必ずしも密度を正確には反 映していないと考えられる (中尾，1989)。しかし，モミ ガラでは土壤と比較すると間隙が大きいため，検出効率 は高いと考えられる。育苗土は前年秋にモミガラ，くん 炭, ピートモスを土に混ぜて準備し，ビニールで被覆し て臭化メチルくん蒸剤処理をおこなっていることから， 発生源となる可能性は低く, 融雪直後の育苗土でュナダ 二類はほとんど検出されていない。一方，モミガラは前 年秋の水稲収穫後, 野つうみにしたものが使用される。ケ ナガコナダニが激発した 1983 年の春期打よび前年秋期 の調査はおこなっていないが，1982年産のモミガラで は 1983 年 10 月までケナガコナダニが比較的高密度で検 出され，オソアシブトコナダニが多発した 1984, 1986 年ともモミガラにおける密度が高かったことから，保温 資材として使用されたモミガラがコナダニ類の発生源で あることが明らかになった。また，栗沢町以外の被害発 生八ウスに打いても，なんらかのかたちでモミガラある いは稻わらが利用されていて，これらが発生源になって 
いると考えられる。コナダニ類は一般に高湿条件を好 及, 湿度 $60 \%$ R. H. 以下では発生しにくいと考えられ ている(松本, 1977)。したがって, コナダ二類の発生 を抑觉るためには，保温資材として利用するモミガラや 稲わらを使用前に十分乾燥させることが必要である。

\section{摘要}

野菜類の育苗期に発生し加害するコナダ二類につい て，1981〜1990 年にかけて北海道内 63 地点で調查を行 った。39 地点の植物体, 土壤, モミガラあるいは稲わ らからケナガコナダニ Tyrohagus putrescentiae (ScHRANK), ホウレンソウケナガュナダニ $T$. similis VolgIN, オオケ ナガコナダニ T. perniciosus ZACHVATKIN, オソアシブト コナダ = Acarus immobilis GRIFPITHs, ロビンネダ= Rhizoglyphus robini CLAPARÈDE が採集された。これらの らち Tyrohagus 属の 3 種が野菜類の苗に被害をあたえて いた。T. putrescentiae はメロソ, スイカ, キュウリ, カ ボチャを，T. similisはメロン，スイカ，キュウリ，力 ボチャ, トマト, ピーマン, 長ネギを, T. perniciosusは メロン,キュウリ，カボチャを加害していた。

被害症状は以下のようにまとめられる。

a) メロン,キュウリ，カボチャ：新葉に小孔，小斑 点ができ, その後, 生育すると奇形になる。

b) スイカ, トマト, ピーマン：葉は光沢を帯び, 褪 色し奇形となる。

c) トマト，長ネギ：苗は萎縮し生育が止まる。

キュウリでのコナダ二類の発生源は保温資材として利 用されたモミガラであることが明らかになった。被害が 発生した他のハウスでも育苗資材としてモミがラか稲わ らが使用され，これらがコナダニ類の発生源になってい ると考㝋られた。

な特，スジブトホコリダニ Tarsonemus bilobatus SusukI はメロン，スイカ，キュウリおよびハクサイから採集さ れ, これらに被害を与えていた。被害症状は葉が光沢を 帯び，裉色し内側に巻さこみ奇形となる。

\section{引用 文 献}

BRuel, W.E. VAN DEN (1940) Un ravageur de l'epinard d'hiver: Tyroglyphus dimidiatus Herm. (longior Gerv.). Bull. Inst. agron. Gembloux 9: 81-99.

江原昭三・真梶徳純 (1975) 農業 ダニ学. 東京 : 全国農村教育 協会, $328 \mathrm{p}$.

藤本 清・足立年一 (1977) ナス育苗床でのケナガコナダニの 発生と防除. 応動昆中国支部会報 19: 1-7.

Griffiths, D.A. (1964) A revision of the genus Acarus L., 1758 (Acaridae, Acarina). Bull. Br. Mus. Nat. Hist. (Zool.) 11 (6) : 415-464.

飯室 勇 (1956) コナダ二類の研究. I. ケナガコナダニ Tyrophagus dimidiatus の生態に関する研究. 衛生動物 7:23-37.

Johnston, D.E. and W.A. BRUCE (1965) Tyrophagus neiswanderi, a new acarid mite of agricultural importance (Acari-Acaridei). Res. Bull. Ohio Agric. Exp. Stn. 977: $1-17$.

小林義明・深沢永光 (1983) コナダニによる農作物被害とその 防除, 並びに同時発生するホコリダニとの関連. 静岡農試 研報 28: 33-42.

LAFFI, F. (1980) Un acaro dannoso ai simenzai di melone: Tyrophagus similis Volgin. Informatore filopatol. 7/8: $17-21$.

松本克彦 (1977) コナダ二類の発育条件. ダ二学の進歩 (佐々 学・青木淳一 編), 東京 : 図鑑の北隆館, pp. 569-579.

中尾弘志 (1988) 野菜類を加害するコナダ二類の北海道におけ る発生と被害. 植物防疫 42: 433-446.

中尾弘志 (1989) 野菜類を加害するコナダニ類に関する研究.

I. ホウレンソウに拈けるコナダニ類の加害実態. 北海道立 農試集報 59: $41-47$.

中尾弘志・黒佐和義 (1988) 日本初記録のコナダ二類 4 種, な らびにそれらによる農作物の被害について．応動昆 32 : $135-142$.

大島司郎 (1977) 屋内麇性コナダ二類の分類. ダ二学の進歩 (佐々 学・青木淳一編). 東京: 図鑑の北隆館, pp. $525-568$.

佐々 学 (1970) 食品・薬品などの害虫としてのダニ類. ダニ 類一その分類・生態・防除 (佐々 学 編), 第 2 版, 東 京: 東大出版会, pp. 368-382 